\title{
KEMAMPUAN PERGANTIAN AUDITOR DAN PRIOR OPINION MEMODERASI PENGARUH POTENSI FINANCIAL DISTRESS TERHADAP OPINI GOING CONCERN
}

\author{
Putu Yudha Asteria Putri ${ }^{1}$ \\ Ida Bagus Putra Astika ${ }^{2}$ \\ Made Gede Wirakusuma ${ }^{3}$ \\ ${ }^{1,2,3}$ Fakultas Ekonomi dan Bisnis Universitas Udayana, Bali, Indonesia \\ e-mail: ydhasteria.putri@gmail.com
}

\begin{abstract}
ABSTRAK
Penelitian ini bertujuan untuk memperoleh bukti empiris kemampuan pergantian auditor dan prior opinion dalam memoderasi pengaruh potensi financial distress pada pemberian opini going concern. Adanya opini going concern disebabkan perusahaan diindikasi tidak mampu lagi untuk melangsungkan hidup perusahaannya. Hasil-hasil penelitian terdahulu mendapatkan hasil yang tidak konsisten dalam hal pengaruh potensi financial distress pada pemberian opini going concern. Adanya pendekatan kontinjensi dapat diselesaikan dalam penelitian ini, dimana variabel pergantian auditor dan prior opinion diduga memoderasi pengaruh potensi financial distress pada pemberian opini going concern. Penelitian ini menggunakan data sekunder. Perusahaan manufaktur yang terdaftar di Bursa Efek Indonesia periode 2009-2015 menjadi populasi dalam penelitian ini dengan jumlah smpel sebanyak 77 sampel yang dipilih dengan teknik purposive sampling.
\end{abstract}

Kata kunci: opini going concern, financial disress, prior opinion, gentianian auditor

\begin{abstract}
This study aimed to get empirical evidence the auditor's ability to change and prior opinion in moderating influence on the potential financial distress Award going concern opinion. There's a going concern opinion because the company indicated no longer able to carry out its life. The results of previous studies get inconsistent results in terms of the potential influence on the provision of financial distress going concern opinion. The existence of a contingency approach can be completed in this study, where the variables change of auditor and prior opinion allegedly moderating influence on the potential financial distress Award going concern opinion. This study uses secondary data. Manufacturing companies listed in Indonesia Stock Exchange period 2009-2015 the population in this study by the amount total of the samples are 77 samples were selected by purposive sampling.
\end{abstract}

Keywords: going concern opinion, financial distress, prior opinion, auditor switching 


\section{PENDAHULUAN}

Beberapa tahun belakangan ini kondisi keuangan dihadapkan dengan rintangan yang cukup besar, hal ini terjadi akibat berbagai permasalahan. Perekonomian Negara-negara di dunia sedikit banyak dipengaruhi oleh krisis ekonomi negara-negara di Eropa. Dunia dikejutkan dengan krisis ekonomi di Amerika Serikat akibat subrime mortage yang terjadi pada tahun 2008. Kesulitan keuangan (financial distress) di perusahaan publik di Indonesia terjadi pada tahun 2005 saat peningkatan harga minyak yang mengejutkan yang diikuti oleh krisis subrime mortage pada tahun 2008. Dampak yang terjadi akibat kerugian besar ini adalah banyak entitas menjadi delisting.

Going concern merupakan kemampuan suatu entitas dapat mempertahankan kelangsungan hidup perusahaanya dalam kurun waktu pantas (SPAP, 2001). Dalam melaksanakan proses audit, yang harus diperhatikan oleh seorang auditor adalah tingkat kegagalan perusahaan dalam mempertahankan kelangsungan hidupnya, karena bagaimanpun keadaan suatu perusahaan kemungkinan suatu entitas mengalami kegagalan akan selalu ada yang mungkin saja disebabkan oleh faktor eksternal serta faktor internal.

Dalam penelitian yang dilakukan Fanny dan Saputra (2005), lebih dari 280 perusahaan yang go public dikategorikan mengalami potensi financial distress. Beberapa penelitian terdahulu melihat seberapa jauh kebangkrutan yang dialami oleh perusahaan-perusahaan tersebut bias diperkirakan dalam beberapa waktu sebelum hal tersebut terjadi (Ross et al., 2012). Hal ini disebabkan karena perusahaan tersebut dianggap tidak mampu untuk mempertahankan kelangsungan 
hidupnya sehingga terancam bangkrut. Penelitian lain yang dilakukan oleh Arnedo dan Lizararaga (2006), dimana ia melakukan studi pada perusahaan di Spanyol mendapatkan hasil financial distress berpengaruh positif terhadap pemberian opini going concern. Dalam penelitian tersebut financial distress dihitung menggunakan model prediksi kebangkrutan Altman yang melihat nilai Zscore, bila makin kecil nilai Zscore perusahaan maka makin mengalami potensi financial distress. Tiga prediksi kebangkrutan yaitu model Altman, model Zmijeweski, dan model Springate oleh Fanny dan Saputra (2005) mendapatkan hasil, model prediksi Altman adalah model terbaik daripada ketiga model yang digunakan untuk dapat mempengaruhi ketepatan seorang auditor dalam pemberian opini audit.

Terjadinya potensi financial distress berdampak pada opini yang diberikan auditor yang dalam hal ini berperan penting dalam memberikan gambaran positif atau negatif dalam masyarakat. Oleh karena itu, pihak manajemen berusaha menghindari opini yang mengungkapkan kekurangan atau keburukan kondisi perusahaan. Perusahaan yang memiliki masalah berharap agar pengungkapan atas kondisi perusahaannya dapat ditunda. Penundaan ini dapat dilakukan dengan menekan auditor dengan motif ekonomi. Namun jika perusahaan kekurangan kekuasaan ekonomi untuk menekan auditor, sebaiknya perusahaan harus mengganti auditor (Nashwa, 2004). Praktik yang dilakukan manajemen ini sering disebut dengan istilah opinon shopping, yaitu usaha suatu perusahaan untuk menghindari opini audit yang tidak diinginkan dengan cara mengganti auditor, 
tentunya dengan asumsi ia mengetahui adanya indikasi opini audit yang akan diberikan auditor tidak sesuai harapan manajemen dan kelak akan berdampak negatif bagi perusahaan.

Hal yang menjadi pertimbangan dan perhatian seorang auditor dalam pemberian opini going concern adalah prior opinion. Perusahaan yang mendapat prior opinion cenderung akan mendapat opini yang sama (Mutchler, 1984). Aktifitas usaha suatu perusahaan pada tahun tertentu tergantung dari keadaan dan kondisi perusahaan yang terjadi di tahun sebelumnya. Didukung oleh penelitian yang dilakukan oleh Aryantika dan Rasmini (2015) dan Cahyono (2014) yang mendapatkan hasil prior opinion berpengaruh positif pada pemberian opini going concern.

Peneliti melihat fenomena jika akuntan dalam membuat keputusan untuk memberikan opini khususnya opini going concern ini tentu akan melihat atau mempertimbangkan histori perusahaan, seperti pergantian auditor dan prior opinion. Oleh sebab itu peneliti memandang perusahaan yang mungkin saja mengalami financial distress pada pemberian opini going concern dipengaruhi oleh opini sebelumnya yang dapat bersifat positif maupun negatif. Berdasarkan alasan tersebut dalam penelitian ini peneliti menempatkan prior opinion sebagai pemoderasi yang mempengaruhi pengaruh financial distress pada pemberian opini going concern dengan menambahkan satu variabel baru sebagai pemoderasi yaitu pergantian auditor dan menggunakan data pengamatan yang lebih baru dari penelitian sebelumnya yaitu dari tahun 2009-2015. Selanjutnya dirumuskan rumusan masalah: 
1) Apakah terdapat moderasi prior opinion terhadap pengaruh model prediksi kebangkrutan pada pemberian opini going concern?

2) Apakah terdapat moderasi pertumbuhan perusahaan terhadap pengaruh model prediksi kebangkrutan pada pemberian opini going concern?

Hasil penelitian-penelitian sebelumnya yang menghasilkan ketidakkonsistenan antar penelitian dengan potensi financial distress yang terjadi karena diindikasikan adanya suatu faktor yang memberikan implikasi potensi financial distress dengan pemberian opini going concern. Ghozali (2006) menyatakan belum terjadinya kesatuan hasil penelitian tersebut kemungkinan disebabkan karena adanya faktor-faktor tertentu atau yang lebih dikenal dengan variabel kontijensi. Govindarajan (1986) juga menyatakan bahwa adanya inkonsistensi kesimpulan penelitian tersebut mampu dijelaskan melalui pendekatan kontinjensi (contingency approach).

Teori harapan menjelaskan bahwa kemampuan suatu tendensi untuk mengambil tindakan melalui cara yang ditentukan atas kemampuan dari suatu harapan bahwa aksi yang diambil diindikasikan dengan hasil yang ada dan sesuai dari hasil itu harapan individu tersebut (Robbins et al., 2008). Opini going concern diharapkan dapat menjadi sinyal yang dapat segera diambilkan tindakan sehingga dapat mengatasi dan menekan risiko yang terjadi (Praptitorini dan Januarti, 2007) karena jika seorang auditor salah dalam pemberian pendapat terhadap emiten yang diauditnya, maka akan menimbulkan gangguan yang lebih kompleks dikemudian waktu, seperti perusahaan yang kondisinya akan semakin 
memburuk karena kesalahan pemberian opini oleh auditor. Secara langsung maupun tidak langsung, auditor yang menerbitkan opini tersebut juga merupakan pihak yang ikut bertanggung jawab.

Pendapat atau opini audit merupakan bagian yang tidak terpisahkan dari laporan audit. Laporan audit sangat penting dalam suatu audit atau proses atestasi lainnya karena laporan tersebut menginformasikan pemakai informasi tentang apa yang dilakukan auditor dan kesimpulan yang diperolehnya. Tugas utama dari auditor independen adalah memberikan opini atas kewajaran laporan keuangan perusahaan. Opini yang diberikan auditor merupakan pernyataan kewajaran dalam semua hal yang material, mengenai posisi keuangan dan hasil usaha serta arus kas sesuai dengan prinsip akuntansi yang berterima umum (SPAP, 2014).

Menurut kamus standar akuntansi dalam Ardiyos (2006:7), opini audit adalah laporan yang diberikan oleh seorang akuntan publik terdaftar sebagai hasil penilaiannya atas kewajaran laporan keuangan yang disajikan perusahaan. Opini audit diberikan oleh auditor melalui beberapa tahap audit sehingga auditor dapat memberikan kesimpulan atas opini yang harus diberikan atas laporan keuangan yang diauditnya (Rahman dan Siregar, 2012).

Subjektivitas dan kehati-hatian seorang auditor muncul ketika melihat keadaan perusahaan klien yang terancam bangkrut dan entitas kemungkinan melakukan auditor switching. Selain itu, penyebab lainnya karena entitas tidak mempunyai kemampuan untuk melunasi biaya yang dikenakan oleh KAP akibat turunnya laba perusahaan, sehingga dapat mengakibatkan suatu situasi yang mendorong entitas melakukan perpindahan terhadap KAP (Nasser et.al., 2006). 
Pergantian auditor secara wajib dan secara sukarela bisa dibedakan pula atas dasar pihak mana yang menjadi fokus perhatian dari isu tersebut. Apabila pergantian auditor terjadi secara sukarela, maka perhatian utama adalah pada sisi klien. Sebaliknya, jika pergantian terjadi secara wajib, perhatian utama beralih kepada auditor (Febrianto, 2009). Pergantian auditor yang terjadi secara wajib memiliki perhatian utama kepada auditor pengganti karena adanya pemberhentian perikatan secara paksa akibat diberlakukannya sebuah peraturan. Saat klien mencari auditor baru, terjadi informasi asimetri diantara klien dan auditor dimana klien lebih superior dalam mengetahui segala informasi tentang perusahaan. Hal tersebut logis karena tentunya klien akan lebih memilih auditor yang sepakat dengan praktik akuntansi perusahaan sedangkan auditor bisa jadi tidak memiliki informasi yang lengkap tentang klien. Apabila auditor kamudian menerima perikatan dengan klien kemungkinan auditor akan cenderung memilih klien karena dua alasan yaitu karena auditor telah mengetahui informasi mengenai perusahaan klien lebih dalam atau hanya karena alasan finansial.

Dalam PMK No. 17/PMK.01/2008 dijelaskan bahwa Kantor Akuntan Publik adalah badan usaha yang telah mendapatkan izin dari Menteri sebagai wadah bagi Akuntan Publik dalam memberikan jasanya. Menurut UU No. 5 Tahun 2011, Kantor Akuntan Publik, yang selanjutnya disingkat KAP, adalah badan usaha yang didirikan berdasarkan ketentuan peraturan perundang-undangan dan mendapatkan izin usaha berdasarkan Undang-undang ini.

KAP adalah sebuah organisasi yang dibuat untuk memberikan jasa akuntansi profesioal kepada perusahaan dan salah satu jasa yang diberikan adalah 
jasa atestasi. Diantara jasa atestasi yang diberikan oleh KAP adalah melakukan audit umum atas laporan keuangan yang dibuat oleh perusahaan, pemeriksaan atas laporan kauangan prospektif dan informasi performa keuangan, serta mereview laporan keuangan perusahaan. Hasil yang diperoleh atas jasa atestasi yang diberikan berupa opini atas laporan keuangan yang meliputi kewajaran penyajian laporan keuangan berdasarkan Prinsip Akuntansi Berterima Umum.

Opini yang dihasilkan oleh auditor dapat menambah keyakinan pihak-pihak yang berkepentingan dalam menilai informasi atas laporan keuangan yang disajikan oleh perusahaan. Dong Yu (2007) juga menjelaskan bahwa bahwa ukuran KAP yang lebih besar secara sistematis menghasilkan kualitas audit yang lebih tinggi. Hal tersebut dapat terjadi karena KAP Big 4 memiliki banyak klien dan sumber daya yang profesional sehingga lebih independen dan tidak tergantung pada salah satu atau beberapa klien saja. Hal tersebut dikarenakan pertama, suatu klien dari KAP kecil memberikan kontribusi yang signifikan terhadap total pendapatan KAP tersebut, kedua, KAP kecil cenderung untuk terlibat hubungan dekat dengan klien sehingga mengganggu independensi KAP tersebut (Suyono et. al., 2013).

Kebangkrutan secara umum diartikan sebagai kegagalan perusahaan dalam menjalankan operasi perusahaan untuk menghasilkan laba. Menurut Harianto dan Sudomo (1995:336), kebangkrutan adalah kesulitan likuiditas yang sangat parah sehingga perusahaan tidak mampu menjalankan operasionalnya dengan baik. Kebangkrutan sebagai suatu kegagalan yang terjadi pada sebuah perusahaan didefinisikan dalam beberapa pengertian (Supardi dan Mastuti, 2003) yaitu:

1) Kegagalan ekonomi (economic distressed) 
Kegagalan dalam arti ekonomi biasanya berarti bahwa perusahaan kehilangan uang atau pendapatan perusahaan tidak mampu menutupi biayanya sendiri. Hal ini berarti bahwa tingkat labanya lebih kecil dari biaya modal atau nilai sekarang dari arus kas perusahaan lebih kecil dari kewajiban. Kegagalan terjadi bila arus kas sebenarnya dari perusahaan tersebut jauh dibawah arus kas yang diharapkan. Bahkan kegagalan dapat juga berarti bahwa tingkat pendapatan atas biaya historis dari investasinya lebih kecil dari pada biaya modal perusahaan yang dikeluarkan untuk sebuah investasi tersebut.

2) Kegagalan keuangan (financial distressed)

Kegagalan keuangan mempunyai arti kesulitan dana, baik dana dalam pengertian kas maupun dana dalam pengertian modal kerja. Sebagian asset liability management sangat berperan dalam pengaturan untuk menjaga agar tidak terkena financial distressed.

Seperti penelitian oleh Sinarwati (2010), Sulistiarini dan Sudarno (2012) dan Pratitis (2012) yang menyimpulkan financial distress berpengaruh signifikan terhadap pergantian auditor. Namun berbeda dengan Susan \& Estralita (2011) menyatakan bahwa potensi financial distress tidak berpengaruh pada pergantian auditor. Berdasarkan alur berfikir dan penelitian-penelitian terdahulu dapat disimpulkan dalam hal ini entitas yang berpotensi mengalami financial distress akan melakukan auditor switching dengan harapan untuk menghindari adanya opini audit going concern yang kemungkinan diterbitkan oleh seorang auditor. Berdasarkan uraian di atas, jadi dapat disimpulkan hipotesis sebagai berikut 
$\mathrm{H}_{1}$ : $\quad$ Pergantian auditor memperlemah pengaruh potensi financial distress pada pemberian opini going concern.

Pengaruh financial distress pada pemberian opini going concern dapat diperkuat atau diperlemah oleh prior opinion yang merupakan opini auditor di tahun sebelumnya atau setahun sebelum tahun penelitian. Rahmadhany (2004), Setyarno dkk. (2006), Praptitorini dan Januarti (2007), serta Wibisono (2013) menemukan bukti bahwa prior opinion mempengaruhi auditor untuk memberikan opini going concern kembali. Penyebab masalah tersebut adalah adanya hipotesis self-fulfilling properchy yang menyatakan bahwa apabila auditor memberikan opini going concern, maka perusahaan akan menjadi cepat bangkrut karena perusahaan akan kehilangan kepercayaan investor yang akhirnya akan membuat para investor maupun kreditur menarik dananya. Perusahaan yang memperoleh opini going concern akan mengalami kesulitan keuangan sehingga akan berdampak terhadap kelangsungan usahanya (Venuti, 2007)

Hal ini juga diperkuat oleh penelitian yang dilakukan olek Dewi (2016) dimana terdapat moderasi prior opinion dan memperlemah pengaruh potensi financial distress yang menggunakan model prediksi Altman pada pemberian opini going concern. Berdasarkan studi-studi tersebut dan alur berpikir jika opini going concern yang didasarkan pada analisis prediksi kebangkrutan juga dipengaruhi oleh opini yang diberikan sebelumnya, maka dapat disusun hipotesis sebagai berikut.

$\mathrm{H}_{2}$ : Prior opinion memperkuat pengaruh potensi financial distress pada pemberian opini going concern 


\section{METODE PENELITIAN}

Penelitian ini berada pada ruang lingkup auditing dengan menganalisis pergantian auditor dan prior opinion sebagai pemoderasi pengaruh model prediksi kebangkrutan pada pemberian opini going concern. Objek dalam artikel menggunakan salah satu industri yang cukup besar yaitu manufaktur yang listing di BEI periode 2009-2015. Data kuantitatif menjadi data yang digunakan yang merupakan data dalam bentuk angka (Sugiyono, 2010:12). Meliputi data keuangan yang diambil dari laporan keuangan auditan perusahaan tahun 20092015. Sedangkan sumber eksternal merupakan sumber tempat data diperoleh yang dapat diartikan bahwa peneliti memperoleh data yang diinginkan secara tidak langsung melalui perantara (Sugiyono, 2010:193). Meliputi data yang diperoleh pada website www.idx.go.id.

Variabel yang dianalisis yaitu opini going concern (GCO), potensi financial distreaa (Z), pergantian auditor (AS), dan prior opinion (PO) dijelaskan sebagai berikut.

1) Opini going concern (GCO) adalah opini audit dimana dalam pertimbangan auditor entitas tidak bisa dan tidak memilki kepastian untuk dapat melanjutkan kelangsungan hidupnya. Dapat dikatakan pula di dalam penilaian auditor adanya risiko entitas berupa ketidakmampuan dalam bertahan untuk kelangsungan bisnisnya. Rudyawan dan Badera (2008) dan McKeown et al., (1991) memiliki pendapat bahwa adanya kemungkinan kegagalan oleh auditor untuk memberi pendapat tentang ada atau tidaknya prediksi 
kebangkrutan di suatu entitas yang ternyata mengalami kebangkrutan dalam tahun yang akan datang. Hal ini diakibatkan entitas tersebut berada dalam posisi kebangkrutan dan kelangsungan usahanya. Pemberian opini going concern dalam penelitian ini diukur dengan menggunakan variabel dummy. Perusahaan yang mendapat opini going concern diberi nilai 1, sedangkan perusahaan yang tidak mendapat opini going concern diberi nilai 0 (Fadilah, 2013).

2) Potensi financial distress (Z) menggunakan model prediksi Altman karena model tersebut adalah model prediksi kebangkrutan terbaik yang digunakan dalam mempengaruhi ketepatan menghitung prediksi financial distress dalam hal pemberian opini audit (Fanny dan Saputra, 2005). Altman di tahun 1968 membangun model untuk menghitung potensi kebangkrutan dengan 22 rasio keuangan dirumuskan sebagai berikut

$$
Z^{\prime}=1,717 Z_{1}+0,874 Z_{2}+3,107 Z_{3}+0,420 Z_{4}+0,998 Z_{5}
$$

3) Pergantian auditor dalam penelitian ini pergantian auditor didefinisikan sebagai ada atau tidaknya pergantian auditor yang dilakukan oleh perusahaan (auditee) (Prastiwi dan Wilsya, 2009) diukur menggunakan variabel dummy.

4) Prior opinion adalah pendapat yang dikeluarkan auditor kepada auditee di tahun sebelumnya yang cenderung mempengaruhi pendapat auditor di tahun berjalan. Perusahaan yang mendapatkan prior opinion mengindikasikan perusahaan tersebut diragukan untuk dapat kembali menjalani aktivitasnya, dimana pengukuran variable ini menggunakan variable dummy. 
Dalam penelitian ini menggunakan populasi seluruh perusahaan manufaktur yang terdapat di BEI dari tahun 2009 sampai tahun 2015, karena perusahaan manufaktur dapat menekan kemungkinan industrial effect (Setyarno dkk., 2006). Selain itu alasan menggunakan industri manufaktur karena industri manufaktur merupakan perusahaan mayoritas yang terdaftar di BEI dibandingkan dengan sektor-sektor lain.

Sampel didalam penelitian ini menggunakan purposive sampling. Kriteria yang digunakan, yaitu (1) Tidak mengalami delisting dari BEI selama periode pengamatan, (2) Mengalami kerugian dalam kurun dua periode laporan keuangan selama periode 2009-2015, (3) Data yang dibutuhkan tersedia sesuai dengan kriteria yang layak, (4) Berganti auditor secara voluntary selama periode 20092015 (5) Rupiah menjadi mata uang yang digunakan.

\section{Tabel 1. \\ Proses Pemilihan Sampel}

\begin{tabular}{ll}
\multicolumn{1}{c}{ Kriteria } & \multicolumn{1}{c}{ Jumlah } \\
\hline $\begin{array}{l}\text { Perusahaan manufaktur yang terdaftar di Bursa Efek Indonesia (BEI) } \\
\text { selama periode 2009-2015. }\end{array}$ & \\
Delisting dari BEI selama periode 2009-2015. & $(39)$ \\
Tidak mengalami kerugian sekurangnya dua periode laporan keuangan & $(76)$ \\
selama periode 2009-2015. & $(7)$ \\
Tidak berganti auditor secara voluntary selama periode 2009-2015 & $(9)$ \\
Tidak menggunakan rupiah sebagai mata uang pelaporan. & $\mathbf{1 1}$ \\
Jumlah perusahaan sampel & $\mathbf{7 7}$ \\
Jumlah data observasi selama periode pengamatan &
\end{tabular}

Tabel 1 menunjukkan bahwa didapat sampel penelitian sebanyak 11 perusahaan manufaktur dengan data observasi sebanyak 77 data. Data kemudian dianalisis dengan pendekatan deskriptif untuk memperoleh gambaran mengenai 
kondisi data, serta hipotesis diuji menggunakan metode Moderated Regression Analysis (MRA) dengan pendekatan regresi logistik karena variabel dependennya bersifat kategorikal

$$
\operatorname{Ln} \frac{G C O}{1-G C O}=\alpha+\beta_{1} Z+\beta_{2} A S+\beta_{3} P O+\beta_{4} Z * A S+\beta_{5} Z * P O+e
$$

Keterangan:

$$
\begin{aligned}
& \operatorname{Ln} \frac{G C O}{1 G C O}=\text { Opini going concern } \\
& =\text { Konstanta } \\
& 1, \quad 2, \quad 3, \quad 4, \quad 5=\text { Koefisien regresi } \\
& \mathrm{Z}=\text { Potensi financial distress } \\
& \text { PO = Prior opinion } \\
& \text { AS } \quad=\text { Pergantian Auditor } \\
& \mathrm{Z} * \mathrm{PO} \quad=\text { Interaksi antara prior opinion dengan potensi financial distress } \\
& \mathrm{Z}^{*} \mathrm{AS} \quad=\text { Interaksi antara pergantian auditor dengan potensi financial } \\
& \mathrm{e} \quad=\text { Error }
\end{aligned}
$$

\section{Uji Kelayakan Model Regresi}

Pengujian kelayakan model regresi digunakan untuk mengetahui apakah variabel independen secara bersama-sama dapat memprediksi variabel dependen atau tidak. Kelayakan model regresi dinilai dengan Hosmer and Lemeshow Goodness of Fit Test. Model ini untuk menguji $\mathrm{H}_{0}$ bahwa data empiris sesuai dengan model. Jika nilai statistik Hosmer and Lemeshow Goodness of Fit Test $\leq$ 0,05 maka $\mathrm{H}_{0}$ ditolak. Hal ini berarti ada perbedaan yang signifikan antara model dengan nilai observasinya sehingga Goodness Fit modelnya tidak baik. Sedangkan jika nilainya > 0,05 maka $\mathrm{H}_{0}$ tidak dapat ditolak, artinya model mampu memprediksi nilai observasinya atau sesuai dengan data. 


\section{Menilai Model Fit (overall model fit test)}

Pengujian ini dilakukan untuk menilai model yang telah dihipotesiskan telah fit dengan data. Hipotesis untuk menilai model fit sebagai berikut:

$\mathrm{H}_{0}$ : Model yang dihipotesiskan fit dengan data.

$\mathrm{H}_{\mathrm{a}}$ : Model yang dihipotesiskan tidak fit dengan data.

Dari hipotesis tersebut maka $\mathrm{H}_{0}$ harus diterima agar model fit dengan data. Statistik yang digunakan berdasarkan fungsi Likelihood. Likelihood (L) dari model adalah probabilitas bahwa model yang dihipotesiskan berdasarkan data input. Untuk menguji $\mathrm{H}_{0}$ dan alternatif, $\mathrm{L}$ ditransformasikan menjadi -2LogL.

Penilaian model fit dilakukan dengan membandingkan antara $-2 \log L$ pada awal $($ Block Number $=0)$, model hanya memasukkan nilai $-2 \log L$ dan konstanta, dengan nilai $-2 \log L$ pada akhir (Block Number $=1$ ), model memasukkan konstanta dan variabel bebas. Apabila nilai $-2 \log L$ Block Number $=0>$ nilai 2LogL Block Number= 1, maka menunjukkan model regresi yang baik. Log Likelihood pada regresi logistik mirip dengan pengertian "Sum of Square Error" pada model regresi, sehingga penurunan nilai Log Likelihood menunjukkan model regresi yang semakin baik.

\section{Koefisien Determinasi}

Koefisien determinasi digunakan untuk mengetahui seberapa besar variabilitas variabel-variabel independen mampu memperjelas variabilitas variabel dependen. Besarnya nilai koefisien determinasi pada model regresi logistik ditunjukkan dengan nilai Nagelkerke $R$ Square $\left(\mathrm{R}^{2}\right)$, yaitu pengujian yang 
digunakan untuk mengukur seberapa jauh kemampuan independen mampu menjelaskan dan mempengaruhi variabel dependen (Ghozali, 2006). Nilai $\mathrm{R}^{2}$ berkisar antara 0 sampai 1 . Jika nilai $\mathrm{R}^{2}$ kecil maka kemampuan variabel independen dalam menjelaskan variabel dependen terbatas. Sedangkan jika $\mathrm{R}^{2}$ mendekati 1 berarti variabel independen mampu memberikan semua informasi yang dibutuhkan untuk memprediksi variabel dependen.

\section{Matrik Klasifikasi}

Matrik klasifikasi menunjukkan kekuatan prediksi dari model regresi untuk memprediksi kemungkinan penerimaan opini audit going concern pada auditee. Dalam output regresi logistik, angka ini dapat dilihat pada Classification Table.

\section{Uji Hipotesis}

Pengujian dengan model regresi logistik yang digunakan dalam penelitian ini adalah untuk mengetahui pengaruh dari tiap-tiap variabel independen tehadap variabel dependen. Pengujian keberartian parameter secara parsial dapat dilakukan melalui uji wald. Kriteria pengujiannya yaitu:

1) Tingkat kepercayaan yang digunakan $95 \%$ atau taraf signifikasi $5 \%(\alpha=$ $0,05)$.

2) Kriteria penerimaan atau penolakan hipotesis didasarkan pada signifikasi $p$ value. Jika taraf signifikasi $\geq 0,05$ hipotesis ditolak, sedangkan jika taraf signifikasi $\leq 0,05$ hipotesis diterima

\section{HASIL DAN PEMBAHASAN}




\section{Statistik Deskriptif}

Dari kriteria sampel yang digunakan, ditemukan sebanyak 77 sampel penelitian dengan hasil uji statistik deskriptif variabel disajikan pada Tabel 2.

Tabel 2.

Statistik Deskriptif

\begin{tabular}{lrrrrr}
\hline & N & Minimum & Maximum & \multicolumn{1}{c}{ Mean } & Std. Deviation \\
\hline Z & 77 & $-2,9476$ & 11,4126 & 1,771125 & 2,7617087 \\
PO & 77 &, 00 & 1,00 &, 3377 &, 47601 \\
AS & 77 &, 00 & 1,00 &, 2987 &, 46069 \\
GCO & 77 &, 00 & 1,00 &, 4026 &, 49364 \\
Z_PO & 77 &,- 4470 & 11,4126 & 1,307604 & 2,8415851 \\
Z_AS & 77 & $-2,9476$ & 1,5971 &, 031013 &, 6135819 \\
Valid N (listwise) & 77 & & & & \\
Sumber: Hasil penelitian, 2016 & & & & &
\end{tabular}

Variabel model prediksi kebangkrutan $(Z)$ memiliki nilai rata-rata sebesar 1,771125 dimana nilai tersebut berada pada skor antara 1,20 dan 2,90 yang disebut sebagai grey area. Hal ini berarti bahwa ada kemungkinan perusahaan sampel mengalami permasalahan keuangan yang dapat mengancamkelangsungan hidup usahanya. Nilai Z-score minimum sebesar -2,9476 dimiliki oleh PT Eratex Djaja Tbk.. pada tahun 2009, dimana hal tersebut menunjukkan perusahaan cenderung berpotensi bangkrut sedangkan nilai Z-score maksimum sebesar 11,4126 dimiliki oleh PT Intanwijaya International Tbk. pada tahun 2010 yang menunjukkan bahwa perusahaan tidak berpotensi bangkrut.

Variabel prior opinion (PO) memiliki nilai rata-rata sebesar 0,3377 yang lebih kecil dari 0,50 menunjukkan bahwa opini audit tahun sebelumnya dengan kode 1, yakni menerima opini going concern lebih sedikit muncul dari 77 sampel. Dari 77 sampel, 27 sampel menerima opini going concern pada tahun sebelumnya dan 50 sampel menerima opini non going concern pada tahun sebelumnya. 
Variabel pergantian auditor (AS) yang memiliki nilai rata-rata yang positif yaitu 0,2987 yang lebih kecil daripada 0,50 menunjukkan bahwa pergantian auditor oleh perusahaan dengan kode 1, lebih sedikit muncul dari 77 sampel. Dari 77 sampel, 23 sampel melakukan pergantian auditor dan 54 sampel tidak melakukan pergantian auditor.

Variabel opini going concern (GCO) memiliki nilai rata-rata sebesar 0,4026 yang lebih kecil dari 0,50 menunjukkan bahwa opini audit dengan kode 1, yakni opini going concern lebih sedikit muncul dari 77 sampel yang diteliti. Dari 77 sampel, 31 sampel menerima opini going concern dan 46 sampel menerima opini non going concern.

\section{Analisis Regresi Logistik}

Analisis regresi logistic berfungsi untuk mengetahui apakah variabel terikat dapat diprediksi oleh variabel bebas Ghozali (2006:225). Hasil disajikan dalam Tabel 3 dan Tabel 4.

Tabel 3.

Hasil Pengujian Model Fit

\begin{tabular}{llrr}
\hline Iteration & -2 Log likelihood & $\begin{array}{c}\text { Coefficients } \\
\text { Constant }\end{array}$ \\
\hline Step 0 & 1 & 103,804 &,- 390 \\
& 2 & 103,804 &,- 395 \\
& 3 & 103,804 &,- 395 \\
\hline \multicolumn{2}{l}{ Sumber: Hasil penelitian, 2016 }
\end{tabular}

Terlihat pada Tabel 3 besarnya nilai -2 Log Likelihood yang pertama yaitu 103,804 yang signifikan pada alpha $(\alpha)$ 5\% sehingga hipotesis nol ditolak, yang berarti sebelum variable dependen dimasukkkan ke dalam model regresi, hanya 
konstanta saja yang fit dengan data dan selanjutnya yaitu pengujian keseluruhan model (overall model fit) yang dapat disajikan pada Table 4

Tabel 4.

Hasil Pengujian Keseluruhan Model (Overall Model Fit Test)

\begin{tabular}{|c|c|c|c|c|c|c|c|c|}
\hline \multirow[b]{2}{*}{ Iteration } & & \multirow{2}{*}{$\begin{array}{c}-2 \text { Log } \\
\text { likelihood }\end{array}$} & \multicolumn{6}{|c|}{ Coefficients } \\
\hline & & & Constant & $\mathrm{Z}$ & $\mathrm{PO}$ & AS & Z_PO & Z_AS \\
\hline \multirow[t]{6}{*}{ Step 1} & 1 & 60,147 & $-1,678$ & , 139 & 1,761 & 1,247 & ,089 & $-1,376$ \\
\hline & 2 & 55,146 & $-2,221$ & ,231 & 2,181 & 1,872 & , 147 & $-2,287$ \\
\hline & 3 & 54,068 & $-2,346$ & ,236 & 2,281 & 2,244 & ,241 & $-2,995$ \\
\hline & 4 & 53,947 & $-2,362$ & ,228 & 2,302 & 2,400 & ,290 & $-3,339$ \\
\hline & 5 & 53,945 & $-2,365$ & ,228 & 2,305 & 2,421 & ,296 & $-3,388$ \\
\hline & 6 & 53,945 & $-2,365$ & ,228 & 2,305 & 2,422 & ,296 & $-3,389$ \\
\hline
\end{tabular}

Sumber: Hasil penelitian, 2016

Tabel 4 menunjukkan model, -2 Log Likelihood dan memiliki angka 53,945, hal ini menunjukkan bahwa terdapat penurunan nilai -2 Log Likelihood sebesar 49,859 .

Pengujian kelayakan model regresi logistik dilakukan agar dapat memberi gambaran bila salah satu variabel bebas mempunyai pengaruh yang lebih dari taraf nyata yang ditentukan. Kelayakan model regresi dinilai dari adanya Goodness of fit test yang diproksikan terhadap nilai Chi-Square pada uji Homser and Lemeshow. Setelah itu peluang taraf nyata dapat dibandingkan terhadap signifikasi 5\% $(\alpha=0,05)$. Hasil pengujiannya disajikan dalam Tabel 5.

Tabel 5. Hasil Pengujian Kelayakan Model Regresi

\begin{tabular}{lcccc}
\hline Step & Chi-square & df & & Sig. \\
\hline 1 & 10,837 & 8 &, 211 \\
\hline Sumber: Hasil penelitian, 2016 & &
\end{tabular}


Tabel 5 menunjukkan nilai signifikasi sebesar 0,211. Nilai tersebut lebih besar dari pada $\alpha=0,05$, jadi $\mathrm{H}_{0}$ diterima. Hal ini dapat diartikan model regresi layak dilakukan analisis selanjutnya

Pengujian multikolinearitas berfungsi dalam melihat besarnya hubungan antara variabel independen di dalam penelitian. Pengujian multikolinearitas dalam model ini menggunakan matrik hubungan antara variabel independen. Regresi yang dapat digunakan tidak ada kaitan antara variabel bebas. Hasil pengujiannya disajikan dalam Tabel 6.

Tabel 6.

Hasil Pengujian Multikolinearitas

\begin{tabular}{llrrrrrr}
\hline & & \multicolumn{1}{c}{ Constant } & \multicolumn{1}{l}{ Z } & \multicolumn{1}{c}{ PO } & \multicolumn{1}{l}{ AS } & \multicolumn{1}{l}{ Z_PO } & \multicolumn{1}{c}{ Z_AS } \\
\hline Step 1 & Constant & 1,000 &,- 869 &,- 775 &,- 762 &, 810 &, 487 \\
& Z &,- 869 & 1,000 &, 693 &, 655 &,- 943 &,- 471 \\
& PO &,- 775 &, 693 & 1,000 &, 546 &,- 759 &,- 508 \\
& AS &,- 762 &, 655 &, 546 & 1,000 &,- 597 &,- 719 \\
& Z_PO &, 810 &,- 943 &,- 759 &,- 597 & 1,000 &, 447 \\
& Z_AS &, 487 &,- 471 &,- 508 &,- 719 &, 447 & 1,000 \\
\hline Sumber:
\end{tabular}

Sumber: Hasil penelitian, 2016

Tabel 6 menghasilkan angka yang jauh di bawah 0,8 . Hal tersebut berarti tidak adanya gejala multikolinearitas antar variabel bebas.

Selanjutnya mengukur besarnya nilai koefisien determinasi dilihat dari Nagelkerke $R$ Square $\left(\mathrm{R}^{2}\right)$, untuk mengetahui berapa besaran variable dependen dapat mempengaruhi variable independen dalam suatu penelitian (Ghozali, 2006).

Tabel 7.

Hasil Pengujian Koefisien Determinasi

\begin{tabular}{|c|c|c|c|}
\hline Step & $\begin{array}{c}-2 \log \\
\text { likelihood } \\
\end{array}$ & $\begin{array}{c}\text { Cox \& Snell R } \\
\text { Square } \\
\end{array}$ & $\begin{array}{c}\text { Nagelkerke R } \\
\text { Square }\end{array}$ \\
\hline 1 & $53,945^{a}$ & ,477 & ,644 \\
\hline
\end{tabular}

Tabel 7 menunjukkan nilai Nagelkerke $R$ Square sebesar 0,644 berarti variabel dependen bias dijelaskan oleh variabel independen sebesar 64,4\%, dan 
sisanya sebesar $35,6 \%$ dijelaskan oleh variabel-variabel lain di luar model penelitian. Atau dapat dikatakan secara bersama variasi variabel potensi financial distress (Z), prior opinion (PO), Pergantian Auditor (AS), interaksi potensi financial distress dengan prior opinion ( $\left.\mathrm{Z}^{*} \mathrm{PO}\right)$, dan interaksi potensi financial distress dengan pergantian auditor $\left(\mathrm{Z}^{*} \mathrm{AS}\right)$ menunjukkan variasi variabel opini going concern sebesar $80,6 \%$.

Hasil pengujian mengenai matrik klasifikasi memudahkan dalam menggambarkan kondisi going concern pada auditee. Matrik klasifikasi dinilai dengan menggunakan angka pada Classification Table. Adapun hasil pengujiannya disajikan dalam Tabel 8.

Tabel 8.

Hasil Pengujian Matrik Klasifikasi

\begin{tabular}{lllrrrr}
\hline & \multicolumn{2}{c}{ Observed } & \multicolumn{2}{c}{ Predicted } \\
& & \multicolumn{2}{c}{ GCO } & \multicolumn{2}{c}{$\begin{array}{c}\text { Percentage } \\
\text { Correct }\end{array}$} \\
\hline Step 1 & GCO & NGC & 41 & 5 & 89,1 \\
& & GC & 9 & & 22 & 71,0 \\
& Overall Percentage & & & & 81,8 \\
\hline
\end{tabular}

Sumber: Hasil penelitian, 2016

Tabel 8 menunjukkan bahwa model regresi memiliki prediksi perusahaan yang mendapatkan opini audit going concern sebanyak 22 perusahaan $(71 \%)$ dan perusahaan yang mendapatkan opini audit non going concern sebanyak 41 perusahaan $(89,1 \%)$. 
Selanjutnya untuk pengujian hipotesis yang menggunakan model regresi logistic dengan tingkat kepercayaan 95\% disajikan dalam Tabel 9.

Tabel 9.

Hasil Pengujian Hipotesis

\begin{tabular}{|c|c|c|c|c|c|c|c|}
\hline & & $\mathrm{B}$ & S.E. & Wald & $\mathrm{df}$ & Sig. & $\operatorname{Exp}(B)$ \\
\hline \multirow[t]{6}{*}{ Step $1^{\mathrm{a}}$} & $\mathrm{Z}$ & ,228 & ,853 & ,072 & 1 & ,789 & 1,256 \\
\hline & PO & 2,305 & 1,168 & 3,894 & 1 & ,048 & 10,025 \\
\hline & AS & 2,422 & 1,235 & 3,843 & 1 &, 050 & 11,263 \\
\hline & Z_PO & ,296 & ,881 & , 113 & 1 & ,737 & 1,345 \\
\hline & Z_AS & $-3,389$ & 1,595 & 4,513 & 1 & 034 & 034 \\
\hline & Constant & $-2,365$ & 1,060 & 4,978 & 1 & 026 & ,094 \\
\hline
\end{tabular}

Berdasarkan Tabel 9, model regresi yang dapat dibentuk sebagai berikut.

$\operatorname{Ln} \frac{G C O}{1 G C O} \mathrm{GCO}=-2,365-0,228 \mathrm{Z}+2,422 \mathrm{AS}+2,305 \mathrm{PO}-3,3389 \mathrm{Z} * \mathrm{AS}+0,296 \mathrm{Z} * \mathrm{PO}+\mathrm{e}$.

Hasil pengujian atas hipotesis pertama $\left(\mathrm{H}_{1}\right)$ dalam penelitian ini menunjukkan bahwa nilai koefisien beta $\left(b_{5}\right)$ adalah $-3,389$ dengan tingkat signifikansi 0,034 yang lebih kecil dari $\alpha=0,05$ yang berarti bahwa $\mathrm{H}_{1}$ diterima. Dengan demikian terbukti bahwa pergantian auditor memperlemah pengaruh potensi financial distress terhadap pemberian opini going concern. Sinarwati (2010), Sulistiarini dan Sudarno (2012) dan Pratitis (2012) yang menyimpulkan bahwa financial distress berpengaruh signifikan terhadap pergantian auditor. Auditor independen bertanggung jawab untuk memberikan opini termasuk penilaian atas kemampuan going concern perusahaan yang mengindikasikan adanya keraguan auditor akan kemampuan perusahaan untuk mempertahakan kelangsungan hidupnya sehingga tidak dapat dipungkiri bahwa opini audit going concern dapat menimbulkan pandangan negatif dari pihak-pihak berkepentingan ke perusahaan yang pada akhirnya berdampak negatif pula terhadap kinerja 
perusahaan. Oleh karena itu, perusahaan berusaha menghindari penerimaan opini audit going concern dengan berbagai cara. Salah satu praktik yang dapat digunakan di mana perusahaan mengganti auditornya dengan harapan agar auditor pengganti memberikan opini yang lebih baik dari opini sebelumnya dan berpengaruh terhadap penerimaan opini going concern.

Hasil pengujian atas hipotesis kedua $\left(\mathrm{H}_{2}\right)$ dalam penelitian ini menunjukkan bahwa nilai koefisien beta $\left(b_{4}\right)$ adalah 0,296 dengan tingkat signifikansi 0,737 yang lebih besar dari $\alpha=0,05$ yang berarti bahwa $\mathrm{H}_{2}$ ditolak. Dengan demikian terbukti bahwa prior opinion tidak memoderasi pengaruh potensi financial distress pada pemberian opini going concern.

Penelitian ini menolak hasil penelitian dari Sasmita (2015), Lestari dan Supadmini (2011) dan Wulandari (2014) yang menyatakan terdapat pengaruh positif antara prior opinion dengan pemberian opini going concern. Pemberian opini going concern tidak semata-mata hanya dilihat dari prior opinion. Perusahaan yang mendapatkan prior opinion yang disebabkan oleh potensi financial distress belum tentu mendapatkan opini going concern di tahun berikutnya, karena kemungkinan adanya perubahan kinerja dari perusahaan tersebut yang mengakibatkan kondisi perusahaan membaik. Penelitian dari Santosa dan Wedari (2007), dan Sihdarma (2014) yang meneliti kecenderungan penerimaan opini audit going concern pada perusahaan manufaktur di BEI pada tahun 2008-2012 menyatakan prior opinion tidah berpengaruh terhadap opini audit going concern.

\section{SIMPULAN DAN SARAN}


Berdasarkan hasil penelitian ini dapat disimpulkan bahwa pergantian auditor memperlemah pengaruh potensi financial distress pada pemberian opini going concern. Perusahaan dengan potensi financial distress cenderung akan mengganti auditornya. Kondisi perusahaan yang tidak pasti dan terindikasi adanya potensi financial distress membut manajemen perusahaan cenderung akan mengganti auditornya dalam hal opinion shopping ataupun mengganti auditor untuk menekan fee audit. Prior opinion tidak memoderasi potensi financial distress pada pemberian opini going concern. Perusahaan yang mendapatkan prior opinion yang disebabkan oleh potensi financial distress belum tentu mendapatkan opini going concern di tahun berikutnya, karena kemungkinan terdapat hal lain yang mempengaruhi pemberian opini going concern tersebut.

Saran yang dapat diberikan, auditor hendaknya dapat mengenali tanda-tanda adanya potensi kebangkrutan suatu perusahaan sehingga tidak lalai dalam memberikan suatu opini audit yang berdampak pada pengambilan keputusan para investor terkait dalam hal keputusan investasi.

\section{REFERENSI}

Arma, E. U. 2013. Pengaruh Profitabilitas, Likuiditas dan Pertumbuhan Perusahaan Terhadap Penerimaan Opini Audit Going Concern (Studi Empiris Perusahaan Manufaktur yang Terdaftar Pada Bursa Efek Indonesia). Jurnal Universitas Negeri Padang.

Aryantika, N. P. P. dan Rasmini, N. K. 2015. Profitabilitas, Leverage, Prior Opinion dan Kompetensi Auditor Pada Opini Audit Going Concern. EJurnal Akuntansi Universitas Udayana 11.2 (2015): 414-425.

Cahyono, D. 2014. Effect of Prior Audit Opinion, Audit Quality, and Factors of Its Audit Opinion Going Concern. Research Journal of Finance and Accounting, Vol. 5, No. 24: 70-77. 
Eko B. S., Januarti, I., dan Faisal. 2006. Pengaruh Kualitas Audit, Kondisi Keuangan Perusahaan, Opini Audit Tahun Sebelumnya, Pertumbuhan Perusahaan terhadap Opini Audit Going Concern. Simposium Nasional Akuntansi IX Padang.

Fadilah, I. 2013. Pengaruh Kadar Kebangkrutan Menurut Model Altman dan Opini Audit Tahun Sebelumnya Terhadap Penerimaan Opini Audit Going Concern. Jurnal Universitas Brawijaya.

Fanny, M. dan Saputra, S. 2005. Opini Audit Going Concern: Kajian Berdasarkan Model Prediksi Kebangkrutan, Pertumbuhan Perusahaan, Dan Reputasi Kantor Akuntan Publik (Studi Pada Emiten Bursa Efek Jakarta). Simposium Nasional Akuntansi VIII: 966-978.

Ghozali. 2006. Aplikasi Analisis Multivariate dengan Program SPSS. Semarang: Badan Penerbit UNDIP.

Govindarajan, V. 1986. "Impact of Participation in the Budgetary Process on Managerial Attitudes and Performance: Universalistic and Contingency Perspective". Decision Science 17. Hal. 496-516.

Hadi, K. K., Gunawan, H., dan Utomo, H. 2015. Pengaruh Likuiditas Solvabilitas dan Model Prediksi Kebangkrutan (Altman Z-Score) Terhadap Pemberian Opini Going Concern (Studi Empiris Pada Perusahaan Manufaktur yang Terdaftar di Bursa Efek Indonesia Tahun 2010-2012). Prosiding Penelitian SPeSIA, 2015: 294-303.

Institut Akuntan Publik Indonesia. 2014. Standar Profesional Akuntan Publik. Jakarta: Salemba Empat.

McKeown, J. Mutchler, J., dan Hopwood W. 1991. Towards an Explanation of Auditor Failure to Modify the audit Opinion of Bankrupt Companies. Journal Practice \& Theory: 1-13.

Mutchler, J. 1984. Auditors Perceptions of the Going Concern Opinion Decision. Journal Practice \& Theory, Vol. 3, No. 2: 17-30.

Praptitorini, M. D. dan Januarti, I. 2007. Analisis Pengaruh Kualitas Audit, Debt Default, dan Opinion Shopping terhadap Penerimaan Opini Going Concern. Simposium Nasional Akuntansi X, Makassar.

Robbins, S. P. dan Judge, T. A. 2008. Perilaku Organisasi, Edisi 12. Jakarta: Salemba Empat.

Rudyawan, A.P dan Badera, I D. N. 2008. Opini Audit Going Concern: Kajian Berdasarkan Model Prediksi Kebangkrutan, Pertumbuhan Perusahaan, 
Leverage, Dan Reputasi Auditor. Jurnal Akuntansi dan Bisnis, Vol. 4 Juli: 129-138.

Santosa, A. F. dan Wedari, L. K. 2007. Analisis Faktor-faktor yang Mempengaruhi Kecenderungan Penerimaan Opini Audit Going Concern. Jurnal Akuntansi dan Auditing Indonesia, Vol. 11, No. 2, Desember: 141158.

Setyarno, E. B., Januarti, I, dan Faisal. 2006. Pengaruh Kualitas Audit, Kondisi Keuangan Perusahaan, Opini Audit Tahun Sebelumnya, Pertumbuhan Perusahaan Terhadap Opini Audit Going Concern. Simposium Nasional Akuntansi IX, Padang.

Sugiyono. 2010. Metode Penelitian Kuantitatif Kualitatif dan R\&D. Bandung: Alfabeta.

Supardi dan Mastuti, S. 2003. Validitas Penggunaan Z-Score Altman untuk Menilai Kebangkrutan pada Perusahaan Perbankan Go Public di Bursa Efek Jakarta. Kompak, No. 7, Januari-April 2003: 68-93.

Wibisono, E. A. 2013. Prediksi Kebangkrutan, Leverage, Audit Sebelumnya, Ukuran Perusahaan Terhadap Opini Going Concern Perusahaan Manufaktur BEI. Jurnal EMBA, Vol. 1, No. 4 Desember: 362-373. 